\title{
Genealogical analysis of large-fruited sweet cherry varieties in accordance with the S-locus of parental forms, and the pattern of inheritance of large-fruited in the presence of S5 and S9 alleles in the genome
}

\author{
Oksana Eremina ${ }^{1 *}$, Victor Eremin ${ }^{1 *}$, and Roman Smirnov ${ }^{2}$ \\ ${ }^{1}$ Krymsk EBS VIR Branch, 12 str.Vavilov, Krymsk, 353384, Russia \\ ${ }^{2}$ N.I. Vavilov All-Russian Institute of Plant Genetic Resources (VIR), 42, 44 str. Bolshaya Morskaya, \\ St. Petersburg, 190000, Russia
}

\begin{abstract}
Annotation. The use of various molecular techniques greatly assists breeders in the selection of parental pairs in directional crossing. The selection of forms with the desired properties at the stage of hybrid progeny is a very laborious work, especially in the selection of fruit crops. This is due to the long life cycle and the impossibility of identifying valuable traits in the first years of the life of a hybrid plant. The use of the definition of S-loci in the genotype of a hybrid of sweet cherry allows at the early stage, before entering fruiting, to isolate genotypes with valuable traits.
\end{abstract}

\section{Introduction}

The selection work with sweet cherries in programs for the creation of new varieties is carried out on the basis of one species - P. avium L. Only a small proportion of old varieties are used, as well as semi-cultivated and wild-growing forms [1]. The main method in sweet cherry breeding is intervarietal hybridization.

Breeders check the mechanism of inheritance of specific traits, as the ability of certain selected forms to transmit desirable properties to offspring $[2,3]$. For the creation of new varieties with the given parameters, it is necessary to study in detail the behavior of parental forms in the process of historical development and their manifestation, the transfer of desired traits to the offspring [4,5]. The work was carried out at the VIR Collections of Plant Genetic Resources within the framework of the VIR state assignment (budget project No. 0662-2019-0004).

The study of the origin of varieties is extremely important for breeding. Clarification of genetic relationship and diversity is possible with using modern molecular methods [6, 7].

\footnotetext{
*Corresponding author: kross67@mail.ru
} 
Recently, such studies have been carried out more and more often for sweet cherries $[8,9$, 10]. Sweet cherry (Prunus avium L.) is a species that is characterized by gametophytic selfincompatibility (GSI), which determines fruit set and therefore the load on the tree. For selection of the best pollinators for the sweet cherry varieties used, you need to know which S-alleles this or that variety contains. For the overwhelming majority of created varieties, information on their S genotypes is still lacking, and the selection of the best pollinators is based solely on the field data [1]. In particular, the use of molecular markers in breeding work to identify genotypes linked to commercially valuable traits significantly facilitates and accelerates the development of new varieties [11, 12]. Self-fertility belongs to one of these characteristics in sweet cherry $[13,14]$. This system is genetically controlled by one multi-allelic locus (S) with two genes that encode specific determinants of the selfincompatibility reaction [15].

In sweet cherries, the S-locus is localized in the sixth pair of chromosomes. According to the latest data, $33 \mathrm{~S}$ alleles have been identified in the culture. Only 13 of them are the most widespread in the world (S1, S2, S3, S4, S5, S6, S9, S10, S12-S14, S16), while the rest are rare [14].

The DNA markers are the tool in the study of the genetic diversity of different cultures [5]. Advances in the next generation sequencing technology (NGS) have made it possible to decipher $77.8 \%$ of the sweet cherry genome sequence [16].

The collection of sweet cherries, concentrated at the Crimean Experimental Breeding Station (EBS) branch of VIR, has 336 genotypes, among them there are self-fertile varieties.

In 2019, the research was carried out in identification of the allelic diversity of a part of the collection and breeding material of the station's sweet cherry. Studying these samples in the field trials on the basis of "weigh of fruit", we found a pattern that the genotypes with established alleles S5 and S9 were distinguished as large-fruited.

The aim of the study was to confirm or refute the established tendency towards largefruited samples with S5 and S9 alleles.

\section{Materials and methods}

According to the literary sources, the genealogical origin of the varieties, taking into account the parental forms, was established. For practical study, 57 varieties of sweet cherry were selected - 12 varieties of domestic selection, 45 foreign ones, including varieties of North America, Western and Eastern Europe. 49 hybrid genotypes (19 crossing combinations) and 9 varieties of offspring from free pollination were analyzed. The points of growth of young shoots of sweet cherry, which grew on the Crimean EBS branch of VIR in the collection plantations of VIR, were selected as a material for the analysis.

The DNA was isolated from sweet cherry leaves by the method of Gavrilenko et al., 2013. PCR analysis was carried out according to the standard methods, the annealing temperatures corresponded to those indicated in the literature [9]. Separation of the obtained PCR products was carried out by electrophoresis in $2 \%$ agarose gels with the addition of ethidium bromide in TBE buffer and visualization of the results in the Bio_Rad agarose gel imaging system.

\section{Results and discussion}

In the world, various scientists have already identified S-alleles for more than 200 varieties of sweet cherry. From the collection of the Crimean OSS for this indicator (S-locus 
establishment), samples with a large fruit size, characterized by the international classifier as "large" and "very large" are studied (Table 1).

Table 1. Grouping of sweet cherry fruits according to the "weight of fruit" classification

A. A. Yusheva [CMEA International Classifier, 1990].

\begin{tabular}{|l|c|}
\hline Fruit parameter & Standard weight, g \\
\hline small & $2,8-3,8$ \\
\hline middle & $3,9-5,3$ \\
\hline large & $5,4-8,3$ \\
\hline very large & $>8,3$ \\
\hline
\end{tabular}

In order to identify the genetic characteristics of sweet cherry varieties in the process of their improvement in a number of generations, according to the literature data and data obtained as a result of field trials, a study of genealogy was carried out $[1,7,9]$. After conducting the genealogical analysis, we traced the transfer of S-alleles to offspring in genotypes characterized by large-fruited. Among the selected varieties created by the hybridological method with established parental forms, S-loci with the following alleles were noted: S1, S2, S3, S4, S4 ', S5, S6, and S9. The genealogy of more than 70 varieties of various ecological and geographical origin has been compiled, most of which have S-locus alleles, varieties with currently unknown alleles, but known in parental forms, are also included (Table 2).

Table 2. Genealogy of modern varieties.

\begin{tabular}{|c|c|c|c|c|}
\hline Veriety & $\begin{array}{c}\text { Origin } \\
\text { parental forms / S } \\
\text { alleles }\end{array}$ & Originator & $\begin{array}{c}\text { weight of } \\
\text { fruit, } g\end{array}$ & $\begin{array}{l}\text { S alleles of } \\
\text { genotype }\end{array}$ \\
\hline Amulet & \multirow{14}{*}{$\begin{array}{c}\text { Drogana Yellow } \\
\times \text { Valery Chkalov } \\
\text { S3S6 } \times \text { S1S9 }\end{array}$} & Krymsk & 12 & S9S? \\
\hline Anshlag & & $\begin{array}{l}\text { Institute of Irrigated } \\
\text { Horticulture (UAAN) }\end{array}$ & 9 & S1S9 \\
\hline Vestochka & & IOS named after UAAN & 9 & unknown \\
\hline Dzherelo & & Donetsk RC & 10 & S1S9 \\
\hline Dilemma & & $\begin{array}{l}\text { Institute of Irrigated } \\
\text { Horticulture (UAAN) }\end{array}$ & 10 & unknown \\
\hline Zagadka & & $\begin{array}{l}\text { Institute of Irrigated } \\
\text { Horticulture (UAAN) }\end{array}$ & 9 & unknown \\
\hline Kolkhoznaya & & $\begin{array}{l}\text { Institute of Irrigated } \\
\text { Horticulture (UAAN) }\end{array}$ & 9 & unknown \\
\hline Mechta & & $\begin{array}{l}\text { Institute of Irrigated } \\
\text { Horticulture (UAAN) }\end{array}$ & 12 & unknown \\
\hline Mirazh & & $\begin{array}{l}\text { Institute of Irrigated } \\
\text { Horticulture (UAAN) }\end{array}$ & 12 & unknown \\
\hline Orion & & $\begin{array}{l}\text { Institute of Irrigated } \\
\text { Horticulture (UAAN) }\end{array}$ & 12 & unknown \\
\hline Pervenets & & $\begin{array}{l}\text { Institute of Irrigated } \\
\text { Horticulture (UAAN) }\end{array}$ & 9 & unknown \\
\hline Prazdnichnaya & & $\begin{array}{l}\text { Institute of Irrigated } \\
\text { Horticulture (UAAN) }\end{array}$ & 9 & unknown \\
\hline Samotsvet & & $\begin{array}{l}\text { Institute of Irrigated } \\
\text { Horticulture (UAAN) }\end{array}$ & $9-10$ & unknown \\
\hline Skazka & & $\begin{array}{l}\text { Institute of Irrigated } \\
\text { Horticulture (UAAN) }\end{array}$ & 10 & S1S9 \\
\hline
\end{tabular}




\begin{tabular}{|c|c|c|c|c|}
\hline Slavyanochka & & $\begin{array}{l}\text { Institute of Irrigated } \\
\text { Horticulture (UAAN) }\end{array}$ & 9 & unknown \\
\hline Temp & & $\begin{array}{l}\text { Institute of Irrigated } \\
\text { Horticulture (UAAN) }\end{array}$ & 9 & unknown \\
\hline Temporion & & $\begin{array}{l}\text { Institute of Irrigated } \\
\text { Horticulture (UAAN) }\end{array}$ & 9 & S3S9 \\
\hline Ulybka & & $\begin{array}{l}\text { Institute of Irrigated } \\
\text { Horticulture (UAAN) }\end{array}$ & 9 & unknown \\
\hline Eyforiya & & Krymsk & 9 & S1S9 \\
\hline Elektra & & $\begin{array}{l}\text { Institute of Irrigated } \\
\text { Horticulture (UAAN) }\end{array}$ & 9 & unknown \\
\hline Epos & & $\begin{array}{l}\text { Institute of Irrigated } \\
\text { Horticulture (UAAN) }\end{array}$ & 11 & unknown \\
\hline $\begin{array}{l}\text { Donetskaya } \\
\text { Krasavitsa }\end{array}$ & & Donetsk RC & 10 & S3S9 \\
\hline Donchanka & \multirow{2}{*}{$\begin{array}{c}\text { Drogana Yellow F/P. } \\
\text { S3S6 } \times \text { S? S? }\end{array}$} & Donetsk RC & 9 & S4S5 \\
\hline Yaroslavna & & Donetsk RC & 9 & S3S5 \\
\hline Karmen & $\begin{array}{l}\text { Drogana Yellow } \times \\
\text { Germersdorf }\end{array}$ & Romania & 9 & S4S5 \\
\hline Meotida & $\begin{array}{c}\text { Drogana Yellow } \times \\
\text { Large-fruited S3S6 } \times \\
\text { S5S9 }\end{array}$ & Donetsk RC & 10 & unknown \\
\hline Aleksandriya & \multirow{2}{*}{$\begin{array}{c}\text { Donetskiy Ugolek } \times \\
\text { Donetskaya } \\
\text { Krasavitsa S3S5 } \times \\
\text { S3S9 } \\
\end{array}$} & Krymsk & 12 & S5S9 \\
\hline Vasilisa & & Donetsk RC & 12 & S5S9 \\
\hline Anons & \multirow{3}{*}{$\begin{array}{l}\text { Napoleon White } \times \\
\text { Pollen Mix }\end{array}$} & $\begin{array}{l}\text { Institute of Irrigated } \\
\text { Horticulture (UAAN) }\end{array}$ & 10 & S5S9 \\
\hline Dachnitsa & & $\begin{array}{l}\text { Institute of Irrigated } \\
\text { Horticulture (UAAN) }\end{array}$ & 12 & S5S9 \\
\hline Krupnoplodnaya & & $\begin{array}{l}\text { Institute of Irrigated } \\
\text { Horticulture (UAAN) }\end{array}$ & 11 & S5S9 \\
\hline Prestizhnaya & $\begin{array}{l}\text { Napoleon White } \times \mathrm{V} \text {. } \\
\text { Chkalov }\end{array}$ & $\begin{array}{l}\text { Institute of Irrigated } \\
\text { Horticulture (UAAN) }\end{array}$ & 10 & S5S9 \\
\hline $\begin{array}{l}\text { Melitopol'skaya } \\
12913\end{array}$ & $\begin{array}{l}\text { Napoleon White } \times \\
\text { Skorospelka }\end{array}$ & $\begin{array}{l}\text { Institute of Irrigated } \\
\text { Horticulture (UAAN) }\end{array}$ & 9 & S4S5 \\
\hline Glesir & \multirow{3}{*}{$\begin{array}{c}\text { Stele } \times \text { Burlat S3S4 } \\
\quad \times \text { S3S9 }\end{array}$} & USA & 9 & unknown \\
\hline Kashmir & & USA & 8,5 & S4S9 \\
\hline Tayton & & USA & 9 & S3S9 \\
\hline Pal & \multirow{3}{*}{$\begin{array}{l}\text { Burlat } \times \text { Stella } \\
\text { S3S9 } \times \text { S3S4 }\end{array}$} & Romania & 9 & S3S9 \\
\hline Peter & & Romania & 9 & unknown \\
\hline Earley Star & & Bolonia & 8,5 & S4S9 \\
\hline Brooks & $\begin{array}{l}\text { Rainier } \times \text { Burlat S1S4 } \\
\times \text { S3S9 }\end{array}$ & USA & 9 & S1S9 \\
\hline Cassandra & \multirow{2}{*}{\begin{tabular}{|l} 
Burlat $\times$ Sunburst \\
S3S9 $\times$ S3S4 '
\end{tabular}} & Czech Republic & 6 & S1S3 \\
\hline Sweet Earley & & Bolonia & 9 & S1S9 \\
\hline Grace Star & $\begin{array}{l}\text { Burlat } \times \text { S.O. S3S9 } \times \\
\text { S? S? }\end{array}$ & Bolonia & 10 & unknown \\
\hline Black Star & $\begin{array}{l}\text { Lapins } \times \text { Burlat S1S4 } \\
\times \text { S3S9 }\end{array}$ & Bolonia & 9,5 & unknown \\
\hline Earley Laurie & $\begin{array}{l}\text { Starking } \times \text { Burlat } \\
\text { S1S2 } \times \text { S3S9 }\end{array}$ & & 8 & S1S9 \\
\hline
\end{tabular}




\begin{tabular}{|c|c|c|c|c|}
\hline Valeria & \multirow{3}{*}{$\begin{array}{l}\text { Donchanka } \times \text { Valeriy } \\
\text { Chkalov S4S5 } \times \text { S1S } 9\end{array}$} & Donetsk RC & 7 & S1S4 \\
\hline Ethics & & Donetsk RC & 9 & unknown \\
\hline Ruxanda & & Donetsk RC & 9 & unknown \\
\hline Farewell & $\begin{array}{c}(\text { Donchanka } \times \text { V. } \\
\text { Chkalov }) \times \text { Dzherelo }\end{array}$ & Donetsk RC & 14 & S2S9 \\
\hline Big Star & $\begin{array}{l}\text { Lapins } \times \text { Lapins } \\
\text { S3S4 }^{\prime} \times \text { S3S4' }\end{array}$ & Bolonia & 7 & S3S4' \\
\hline Valera & $\begin{array}{c}\text { Giant } \times \text { Windsor } \\
\text { S3S5 }\end{array}$ & Canada & 8 & S1S3 \\
\hline Alex & $\begin{array}{c}\text { Ven } \times \text { John Innes } 2420 \\
\text { S1S3 } \times \text { S3S4 }\end{array}$ & Romania & 8 & S3S3' \\
\hline Amide & $\begin{array}{c}\text { Cordia } \times \text { Vic S3S6 } \times \\
\text { S2S4 }\end{array}$ & Czech Republic & 7 & S3S4 \\
\hline Wanda & \multirow{2}{*}{$\begin{array}{c}\text { Vein } \times \text { Cordia S1S3 } \times \\
\text { S3S6 }\end{array}$} & Czech Republic & 7 & S1S6 \\
\hline Fabiola & & Czech Republic & 7 & unknown \\
\hline Tehloven & $\begin{array}{l}\text { Cordia } \times \text { Vein S3S6 } \times \\
\text { S1S3 }\end{array}$ & Czech Republic & 9 & S3S6 \\
\hline Vandaley & \multirow{4}{*}{$\begin{array}{c}\text { Ven } \times \text { Stella S1S3 } \times \\
\text { S3S4 }\end{array}$} & Canada & 7 & unknown \\
\hline Sunburst & & Canada & 7 & S2S4 \\
\hline Silvia & & Canada & 7 & S3S4 \\
\hline Lapins & & Canada & 7 & S1S4 \\
\hline Tamara & \multirow{2}{*}{$\begin{array}{l}\text { Large-fruited } \times \text { Van } \\
\quad \text { S5S9 } \times \text { S1S3 }\end{array}$} & Czech Republic & 11 & S1S9 \\
\hline Tim & & Czech Republic & 9 & S3S5 \\
\hline Santina & $\begin{array}{l}\text { Stella } \times \text { Samit S3S4 } \\
\times \text { S1S2 }\end{array}$ & Canada & 7 & S1S4' \\
\hline Selakh & $\begin{array}{l}(\text { Rainier } \times \text { Bing }) \times \\
\text { Stella }\end{array}$ & USA & 7 & S3S4' \\
\hline Vega & $\begin{array}{l}\text { Bing } \times \text { Victor S3S4 } \times \\
\text { S2S3 }\end{array}$ & Canada & 6 & S2S3 \\
\hline Rainier & $\begin{array}{l}\text { Bing } \times \text { Ven S3S4 } \times \\
\text { S1S3 }\end{array}$ & USA & 7 & S1S4' \\
\hline Skina & $\begin{array}{l}(\text { Bing } \times \text { Stella }) \times(\text { Ven } \\
\times \text { Stella })\end{array}$ & Canada & 7 & S1S4' \\
\hline Simfoniya & $\begin{array}{l}\text { Lapins } \times \text { Bing S3S4'x } \\
\text { S3S4 }\end{array}$ & Canada & 6 & S3S4' \\
\hline Kiyevlyanka & $\begin{array}{l}\text { Melitopol'skaya } \\
\text { Chernaya S.O. }\end{array}$ & Ukraine & 9 & S6S9 \\
\hline Merchant & Merton Gloria S4S6 & England & 10 & S4S9 \\
\hline Regina & $\begin{array}{l}\text { Schneiders Spot x } \\
\text { Rub }\end{array}$ & Germany & 6 & S1S3 \\
\hline Sandra & Cordia $\times$ s-c No. 13 & Czech Republic & 6,5 & S3S4 \\
\hline Svitkhart & \multirow{2}{*}{$\begin{array}{l}\text { Ven } \times \text { Newstar S1S3 } \\
\text { x S3S4 ' }\end{array}$} & Canada & 6 & S3S4' \\
\hline Selesta & & Canada & 7 & S1S4' \\
\hline Stokkato & Sweetheart $\times$ S.O . & Canada & 6 & S3S4' \\
\hline Suvenir & $\begin{array}{l}\text { spontaneous seedling } \\
\text { unknown origin }\end{array}$ & France & 8 & S3S9 \\
\hline Erlayz & & France & 9 & S1S9 \\
\hline
\end{tabular}

$* \mathrm{~F} / \mathrm{P}$ - Free pollination

$\bullet ?$ - the allele unknown

A regularity was revealed in the presence of a locus containing S5 or S9 alleles in the genome, this genotype was characterized as "very large". 
The transmission of S-allele No. 5 and No. 9 in a number of generations was monitored when using these varieties as parental forms.

The results of genealogical analysis indicate that varieties created in Eastern Europe are characterized by a high frequency of occurrence of S5 and S9 alleles, and varieties characterized by "very large" fruits also prevail among breeders of this region [14].

At the same time, varieties of Western Europe and North America, mainly have alleles S3, S4, S4'-mutant and S6, the fruit weight of which varies from 6.0 to 8.5 grams and are classified as "large". Only when the Burlat variety is included in the breeding, genotypes with the S9 allele appear in the offspring.

There are more than 50 genotypes with known $\mathrm{S}$ - alleles and established parental forms in our studies. Analyzing them together with the weight of the fetus, it was revealed that in most cases the samples carrying the S5 or S9 alleles had a fetal size of more than 9 grams (Fig. 1).

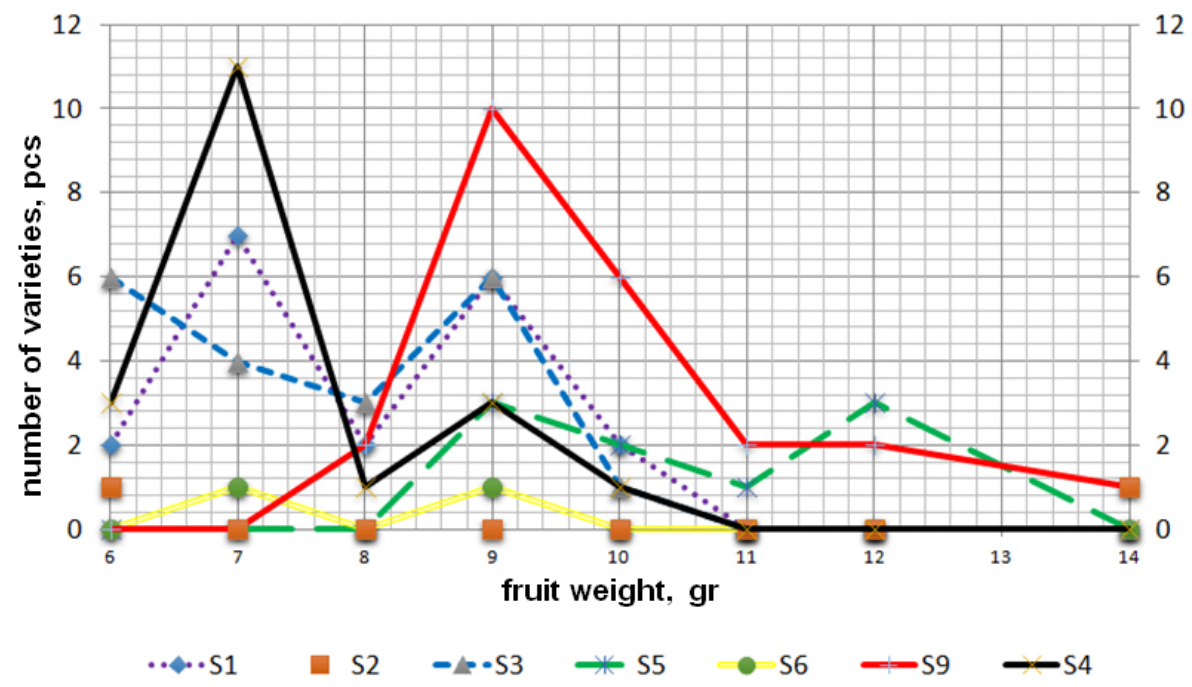

Fig. 1. Biological weight of the variety according to the presence of the S-locus.

The term "biological" weight of the variety means fruit's actual, average value while growing a tree in the natural conditions without the use of plant bioregulators (such as gibberellins), which artificially increase the number of cells and their size.

Among the samples identified by origin with the S9 allele, the analysis revealed varieties with the weight of the fruits 8.5 grams - 2 pcs., $9 \mathrm{~g}-10$ pcs., $10 \mathrm{~g}-6$ pcs., 11 g - 2 pcs., $12 \mathrm{~g}-2$ pcs. and $14 \mathrm{~g}-1$ sample. At the same time, there are no genotypes the weight of the fruit less than 8 grams with the searched allele. Among the studied varieties carrying the S5 allele, there were only 9 accessions, which were also classified as the "very large" fruits, over $8 \mathrm{~g}$.

Mostly in the selection of sweet cherries in Western Europe and North America, the local ancient varieties were used. Especially often they were - Gödelfingen (S1S3), Germersdorf (S3S12), Burlat (S3S9), Ven (S1S3), Bean (S3S4), Lambert (S3S4) and Imperial Francis (Franz Joseph) (S3S4). Also created by Canadian breeders, the varieties such as Stella (S3S4 '), Lapins (S3S4'), Sweethart (S3S4 ') are used in the further work to create new self-fertile varieties. In European countries, the varieties such as Vittoria (S3S14), Vic (S2S4), Cordia (S3S6) and Merton Glory (S4S6), are used in breeding programs for obtaining late-ripening large-fruited varieties. In the Eastern European Genetic Center, primarily in Russia and Ukraine in the zone of 
traditional sweet cherry cultivation, breeders used in their programs the varieties Drogana yellow (S3S6), Franz Joseph (S3S4), Napoleon Belaya and Bigarro Burlat (S3S9) introduced from Western Europe. When creating new varieties, the genotypes such as Donchanka (S4S6), Valeriy Chkalov (S1S9), Large-fruited (S5S9), Dzherelo (S1S9) and Donetskaya Krasavitsa (S3S9) - showed a high combinative ability. Their offspring inherit large-fruited form from the parental form.

During the selection of hybrids, breeders are guided by the choice of the largest and the most promising genotypes, and it is possible that they rejected samples that also had the desired alleles, but were not distinguished by fruit weight. In order to prove the regularity of large-fruitedness and the presence of S5 and S9 alleles in the genome, it is necessary to study the transfer of the trait to the offspring of all obtained hybrids in practice.

The hybrid fund of sweet cherry genotypes at the Crimean RSS branch of The Institute of Plant Industry, currently has more than 10,000 samples. The scientists are conducting targeted breeding work to create productive, adaptive, large-fruited, and self-fertile varieties. The selection involves genotypes of various ecological and geographical origins such as Valery Chkalov, Large-fruited, Alexandria, Skina, Alaya, Lapins, Zagadka, Amulet, Tamara, Vasilisa.

The resulting hybrids were identified by the presence of the S-locus. It was found that the used parental forms in the breeding have S5 and S9 alleles in the genotype and transmit them to their offspring, and the hybrids that have entered fruiting have a very large fruit size (Table 3, Fig. 2).

Table 3. Alleles of the S-locus identified in the breeding material of the Crimean RSS in hybrids of different combinations of crosses.

\begin{tabular}{|c|c|c|c|c|c|c|}
\hline № & \multicolumn{2}{|c|}{ Crossing / hybrid combination } & Genotype $q$ & Genotype ${ }^{\lambda}$ & $\begin{array}{l}\text { Genotype of } \\
\text { hybrids }\end{array}$ & $\begin{array}{c}\text { Fruit } \\
\text { weight, } \mathrm{g}\end{array}$ \\
\hline \multirow[t]{6}{*}{1} & \multicolumn{2}{|c|}{ Alexandria $\times$ V. Chkalov } & $S 4 S 9$ & S1S9 & & \\
\hline & 1 & $\begin{array}{r}/ 19-12- \\
147\end{array}$ & & & $S(1,5) S 4$ & 10,3 \\
\hline & 2 & $\begin{array}{r}19-12- \\
160\end{array}$ & & & $S 4 S 9$ & 9,8 \\
\hline & 3 & $\begin{array}{r}19-12- \\
176\end{array}$ & & & $S 4 S 9$ & 9,5 \\
\hline & 4 & $\begin{array}{r}19-12- \\
154 \\
\end{array}$ & & & $S(1,5) S 9$ & 13,6 \\
\hline & 5 & $\begin{array}{r}/ 19-12- \\
178\end{array}$ & & & $S(1,5) S 9$ & 10,3 \\
\hline \multirow[t]{2}{*}{2} & \multicolumn{2}{|c|}{ Alexandria $\times$ Lapins } & $S 4 S 9$ & S1S4 & & \\
\hline & 6 & $\begin{array}{r}/ 19-11- \\
131\end{array}$ & & & $54 S 9$ & 9,2 \\
\hline \multirow[t]{2}{*}{3} & \multicolumn{2}{|c|}{ Lapins $\times$ Zagadka } & S1S4 & $S 6 S 9$ & & \\
\hline & 7 & $\begin{array}{r}/ 19-11- \\
134 \\
\end{array}$ & & & $S 9 S(6)$ & 9,0 \\
\hline \multirow[t]{2}{*}{4} & \multicolumn{2}{|c|}{ Amulet $\times$ Lapins } & $S 9 S x$ & S3S4 & & \\
\hline & 8 & $\begin{array}{r}19-11- \\
139 \\
\end{array}$ & & & $S 9 S(1,5)$ & 10,3 \\
\hline \multirow[t]{2}{*}{5} & \multicolumn{2}{|c|}{ Vasilisa $\times$ Donchanka } & S5S9 & $S 4 S 5$ & & \\
\hline & 9 & $\begin{array}{r}/ 19-11- \\
153\end{array}$ & & & $S 5 S 9$ & 9,3 \\
\hline \multirow[t]{3}{*}{6} & \multicolumn{2}{|c|}{ Large-fruited S.O. } & $S 5 S 9$ & $S x S x$ & & \\
\hline & 10 & $\begin{array}{r}19-11- \\
134 \\
\end{array}$ & & & S9Sx & 10,1 \\
\hline & 11 & /1912- & & & S3S9 & 9,8 \\
\hline
\end{tabular}




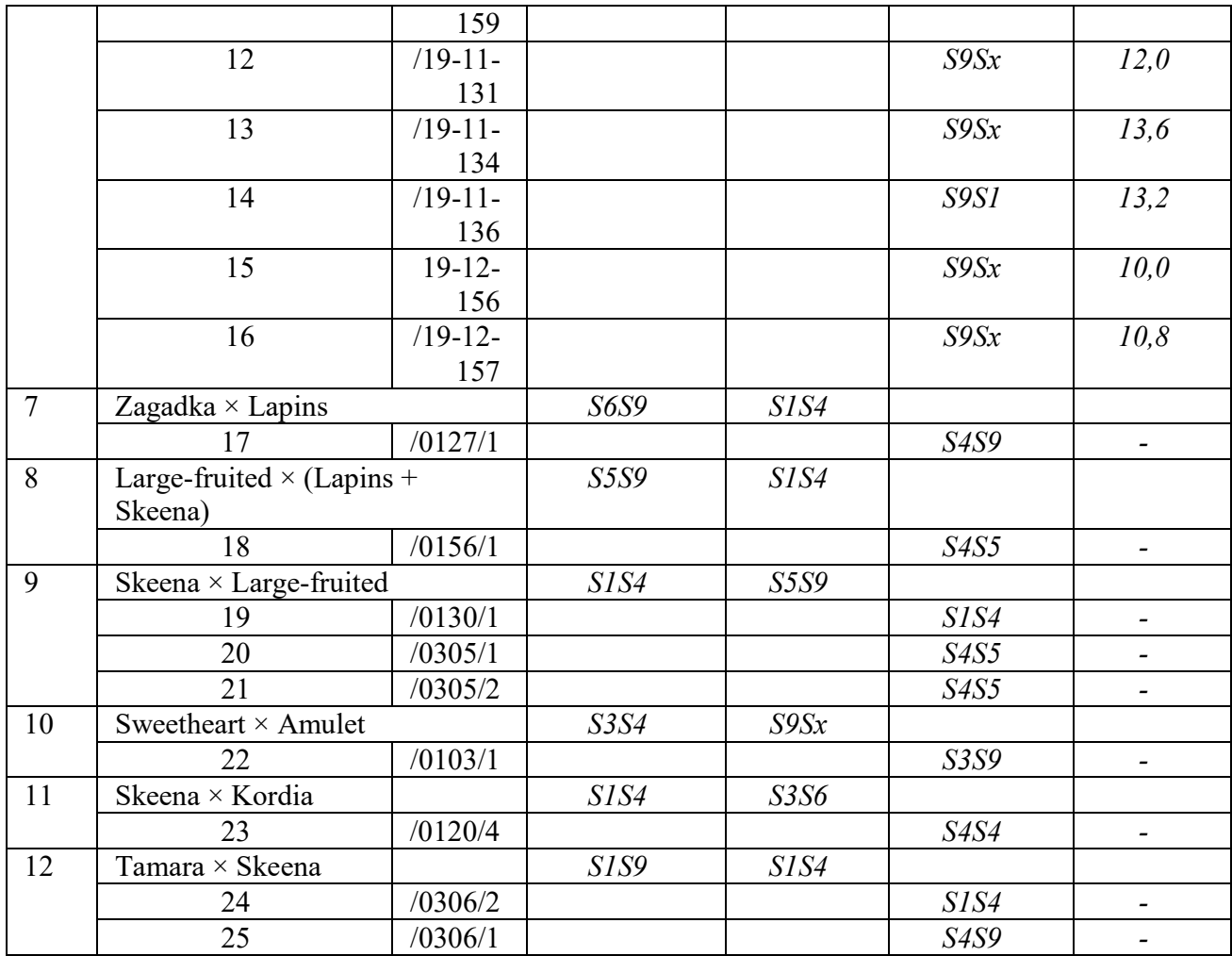

The probability of choosing an allele from the parent's genotype is $1 / 2$; therefore, if there are two alleles in one genome, the inheritance takes on a directed form. The genotype which has both S5 and S9 alleles is simultaneously appearing to be a donor of the transmission of the desired trait to the offspring.

For the testing purposes, the samples of various years of hybridization were taken, the hybrid families from 1 to 6 (with the numbers similar to 19/12/147) were obtained in 2013 and planted in the garden in 2015, and entered fruiting in 2020.

The weather conditions in the spring of 2020 were unfavorable and return frosts down to minus $8{ }^{\circ} \mathrm{C}$ damaged the fruit formations by $45-60 \%$. However, the optimal temperature established during the flowering period, which promoted good fruit set.

The genotypes selected in 2019 with the desired alleles during the initial study had a fruit size characterized as "large" and "very large" (Fig. 2).

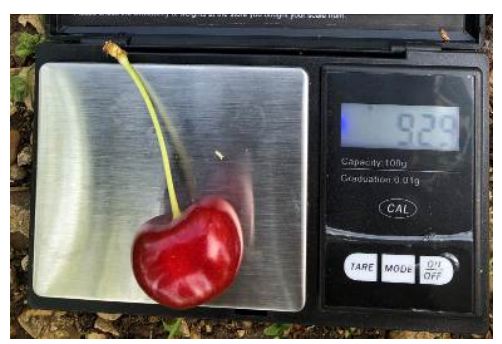

Vasilisa $\times$ Donchanka 19/11/153

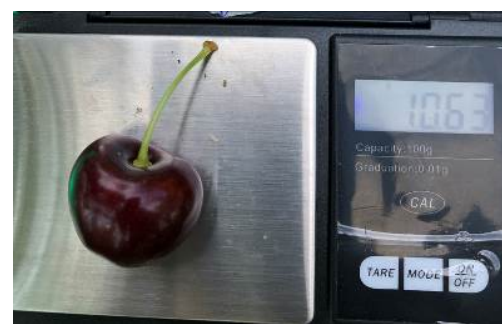

Alexandria $\times$ V. Chkalov /19-12-176 


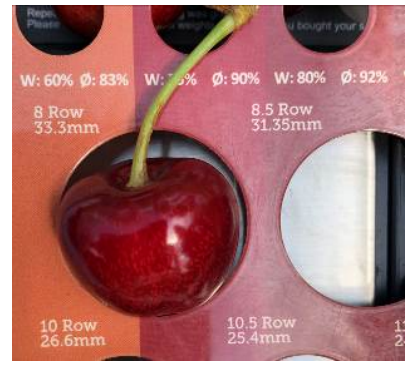

Alexandria $\times$ V. Chkalov /19-12-154, 33mm in diameter corresponds to 13 grams of weight

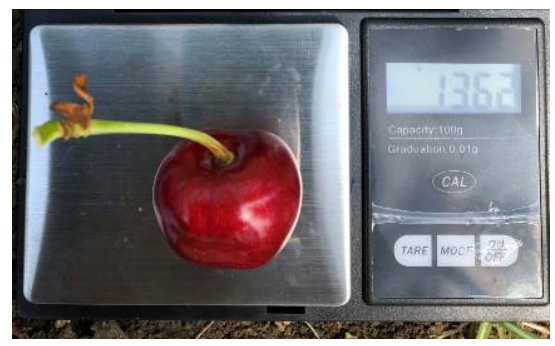

Large-fruited S.O./19-11-134

Figure: 2. Primary study of sweet cherry hybrids of selection of the Crimean RSS (2020).

The hybrids from crosses from 7 to 12 serial numbers (like / 0127/1) were hybridized in 2018. At the time of the study, they are growing in a greenhouse. Even with the use of methods that accelerate the selection of sweet cherries, they will enter fruiting no earlier than three years later. However, according to the results of PCR analysis, the presence of alleles S5 and S9 in the genotype was established.

To establish the correlation and mathematical confirmation of the assumptions of the pattern, it is necessary to conduct further research and increase the sampling options.

\section{Conclusion}

Thus, it can be assumed that the use of PCR analysis for breeding hybrids will allow at the early stage select genotypes that can be characterized by a "very large" fruit weight. The knowledge of the S-locus of the genome of parental forms will make it possible to purposefully form maternal and paternal lines for selective use in order to obtain hybrids with fruits of "large" and "very large" sizes.

\section{References}

1. O. V. Eremina, Proceedings on applied botany, genetics and breeding, 179(3), 302-314 (2018) https://doi.org/10.30901/2227-8834-2018-3-302-314

2. Ya. I. Ivanovych, K. M. Udovychenko, M. O. Bublyk, R. A. Volkov, Cytology and genetics, 51(1), 51-60 (2017) http://nbuv.gov.ua/UJRN/CLG_2017_51_1_8

3. F. Biscarini, N. Nazzicari, M. Bink, P. Arús, M. J. Aranzana, I. Verde, S. Micali, T. Pascal, B. Quilot-Turion, P. Lambert, C. da Silva Linge, I. Pacheco, D. Bassi, A. Stella, L. Lossini, BMC Genomics., 18(1), 432 (2017) https://doi.org/10.1186/s12864017-3781-8.

4. M. Meland, F. M. Maas, Å. Jørgensen, Acta Hortic., 1235, 353-358 (2019) https://doi.org/10.17660/ActaHortic.2019.1235.48

5. J. Quero-García, J. A. Campoy, T. Barreneche, L. L. Dantec, B. Wenden, M. Fouché, E. Dirlewanger, H. Silva, L. Cai, A. Iezzoni, Acta Hortic., 1235, 1-14 (2019) https://doi.org/10.17660/ActaHortic.2019.1235.1

6. Ya. Ivanovych, R. Volkov, J. Hortic. Sci. Biotechnol., 93(1), 64-72 (2017) https://doi.org/10.1080/14620316.2017.1342568.

7. A. Marchese, F. P. Marra, D. Priolo, T. Caruso, D. Giovannini, A. Leone, R. Mafrica, S. Pangallo, M. Palasciano, F. R. De Salvador, ActaHortic., 1161, 41-46 (2017) https://doi.org/10.17660/ActaHortic.2017.1161.6 
8. A. M. Cachi, A. Wünsch. J. Exp. Bot., 62(6), 1847-1856 (2011) https://doi.org/10.1093/jxb/erq374

9. K. Sharma, A. M. Cachi, P. Sedlák, A. Skřivanová, A. Wünsch. J. Hortic. Sci. Biotechnol., 91(2), 117-121 (2016) https://doi.org/10.1080/14620316.2015.1110997.

10. A. Cabrera, U. R. Rosyara, P. De Franceschi, A. Sebolt, S. S. Sooriyapathirana, E. Dirlewanger, J. Quero-Garcia, M. Schuster, A. F. Iezzoni, E. van der Knaap, Tree Genet. Genomes, 8, 237- 247 (2012) https://doi.org/10.1007/s11295-011-0436-9.

11. A. M. Cachi, A. Wunsch, A. Vilanova, M. Guardia, M. Ciordia, N. Aleta, Plant Breed., 136(1), 126-131 (2017) https://doi.org/10.1111/pbr.12450

12. A. Ipek, H. Gulen, M. E. Akcay, M. Ipek, S. Ergin, A. Eris, Genet. Mol. Res., 101, 253-260 (2011) http://doi.org/10.4238/vol10-1gmr1024

13. A. Lisek, E. Rozpara, A. Głowacka, D. Kucharska, M. Zawadzka, Hort. Sci.. 42(1), 13-21 (2015) https://doi.org/10.17221/103/2014-HORTSCI.

14. G. T. Azizi, A. Albouchi, A. C. José, M. Magid, A. H. Ben, Y. Ammari, Int. J. Agr. Agri. R., 9(3), 45-56 (2016) https://www.researchgate.net/publication/309727946

15. L. Cai, R. E. Voorrips., E. van de Weg, C. Peace, A. Iezzoni, Mol. Breed., 37, 85 (2017) https://doi.org/10.1007/s11032-017-0689-6

16. K. Shirasawa, K. Isuzugawa, M. Ikenaga, Y. Saito, T. Yamamoto, H. Hirakawa, S. Isobe, DNA Res, 24(5), 499-508 (2017) https://doi.org/10.1093/dnares/dsx020 